\title{
A NÉPZENEOKTATÁS JELENLÉTÉNEK VIZSGÁLATA SZAKGIMNÁZIUMI TANULÓK KÖRÉBEN
}

\author{
EXPLORATION OF FOLK MUSIC EDUCATIONAL \\ ASPECTS AMONG VOCATIONAL HIGH SCHOOL \\ STUDENTS
}

\author{
Dragony Gábor
}

\begin{abstract}
In this research, we explore the curricular and extracurricular scenes of folk music education via paper-based questionnaire data collection. 103 students, from grade 9-14th of eight vocational secondary schools that teach folk music (as well) participated in this study. They represent different regions of Hungary. These art high schools offer full-time folk music training (field of study), where one can choose his/her specialization, i.e., instrument and/or singing. The questionnaire on one hand examines background variables and on the other hand it surveys the students' views on the non-cognitive components of the curricular and extracurricular scene of folk music education, together with the attendance of events, their experience values, and developmental prospects. The answers highlight the similarities and differences that characterize the school and out-of-school folk music scenes. By further analysis of the gained data, new trends need to be identified, as there is almost no research on folk music education in Hungary. The students' answers define the characteristics of the curricular and extracurricular scenes. It is necessary and possible to develop the methodologies of the scenes based on those. One such peculiarity in both areas is the lack of folk music field collection. However, this is essential and important in the professional training of future folk musicians, in which all professionals, educators, and folk music researchers agree.
\end{abstract}

Keywords: curricular and extracurricular folk music education, folk music camps, folk music, folk culture

\section{Bevezetés}

A népzeneoktatás megjelenése a kurrikuláris oktatás helyszínein csupán néhány évtizedes múltra tekint vissza. Az extrakurrikuláris helyszíneken azonban korábban és a jelenlegi rendszerrel párhuzamosan is megjelentek olyan oktatási formák (Kiss, 2006), amelyekröl tudományos értelemben keveset tudunk. Doktori kutatásomban - melynek része a jelen vizsgálat - arra szeretnénk választ kapni, milyen hasonlóságok és különbségek vannak a népzeneoktatás szerepeit tekintve a kurrikuláris és extrakurrikuláris helyszíneken. Gyakorló népzenetanárként sokszor tapasztalom a terület feltáratlanságából, a kevés kutatásból és a kisszámú szakirodalomból fakadó hiányosságokat. A népzeneoktatásban az extrakurrikuláris színtér nyújtotta lehetőségekről (Báthory, 1997; PáskuMünnich, 2000; Nahalka, 2003; Bárdossy, 2011) köznapi értelemben sok szó esik, az „előnyeit”, hatását tudományos alapra helyezve, empirikus kutatással is szükséges bizonyítani.

A népzeneoktatásnak nagyon sok közös pontja van a zenei müvészeti neveléssel, de vannak speciális céljai is (Váradi, 2019; Váradi, 2010; Stachó, 2008; Mark, 2002; Johansen, 2010). Mind az iskolai, 
mind az iskolán kívüli népzeneoktatás a hagyományokban gyökerezik, a táncházmozgalom indította útjára, és a népzenekutatás tudományos eredményein is alapul (Dobszay, 2009; Sárosi, 2003; Sebö, 2009; Halmos, 2006). A hagyományban élő népzeneoktatás hosszú időn keresztül a népzenészek képzésére vonatkozott (Agócs, 2010; Könczei, 2011). Ez határozta meg a mára kialakult intézményesített és intézményen kívüli népzeneoktatást. Nemcsak a táncházak igényeltek képzett népzenészeket és népzenét oktatókat, hanem a mozgalom nyomán létrejött népdalköröknek, zenekaroknak is szükségük volt a megfelelö szakmai segítségre (Béres, 1979). Ezt felismerve indult meg tanfolyamok sora különböző intézményekben, majd alapfokú zeneiskolák és középiskolák is megkezdték müködésüket. Ezek száma, tartalmi szabályozása folyamatosan változott és változik (Dragony, 2018).

A népzeneoktatás funkciói, céljai, feladatai, azaz szerepei az oktatás különböző színterein hasonlóak és különbözőek. Az extrakurrikuláris jelző vonatkozik a kötelező tanórán kívüli iskolai, illetve iskolán kívüli alkalmakra is, ezeket a szakirodalom alapján sokféle szempont szerint lehet elkülöníteni és összehasonlítani (Trencsényi, 2006). Extrakurrikuláris népzeneoktatási színtérnek tekinthetők a szakkörök, táborok, szakmai fórumok (továbbképzések, tanfolyamok, találkozók, fesztiválok), táncházak, koncertek, részvétel zenekarban, gyüjtőutak, versenyek és az iskolán kívüli magánoktatás (Dragony, 2017). Az extrakurrikuláris népzeneoktatás a müvészeti nevelésnek az a területe, mely értékeket képvisel és a hagyományon alapul. Az oktatásba bevont föbb szereplöi a még élö, aktívan zenélő hagyományőrző mesteremberek. A velük való találkozásoknak, a néprajzi környezet megismerésének megkerülhetetlen alkalmai a gyüjtőutak. A különféle oktatási alkalmak, színterek a növendékek zenei fejlődése mellett folklór háttérismereteket biztosítanak élményeket nyújtó módszerekkel.

Kutatásunkban a következő kérdésekre keressük a választ: Hogyan alakul a tanulók „mozgása” a kurrikuláris és az extrakurrikuláris színterek között? Az iskola szervezésében vagy az iskolán kívül vesznek részt többször a gyerekek a felsorolt alkalmakon? Mennyire érzik a növendékek szakmai fejlődésük színterének az extrakurrikuláris alkalmakat? A család társadalmi, gazdasági és kulturális háttere összefüggésben van-e a népzenetanulással?

Kutatási kérdéseinkhez a következő hipotézisek kapcsolódnak: H1: Feltételezésünk szerint a kurrikurális és az extrakurrikuláris színtér egymástól nem független, az „átjárás” mindkét arányban megvalósul. Feltevésünk továbbá az, hogy nagyobb az aránya azoknak a tanulóknak, akik a kurrikuláris színtérről keresnek fel extrakurrikuláris helyszíneket is (például szakmai tábort, táncházat), mint azoknak, akik utóbbi színtérről lépnek az intézményes oktatásba. H2: Feltételezésünk szerint a közoktatási rendszerből és szabályozásából adódóan a növendékek ritkábban jutnak el népzeneoktatási alkalmakra az iskola szervezésében annak ellenére, hogy a szakgimnáziumi tanterv rögzíti ennek lehetöségét és szükségességét. H3: Úgy véljük, a növendékek szerint teljes mértékben vagy nagymértékben hozzájárulnak az extrakurrikuláris népzeneoktatási színterek a saját szakmai fejlődésükhöz. H4: Feltételezzük, hogy a jobb anyagi helyzetben lévő és magasabb iskolai végzettségü szülőkkel rendelkező növendékek gyakrabban vesznek részt extrakurrikuláris népzeneoktatási alkalmakon. A háttérváltozók részletes elemzése alátámaszthatja azt a megállapítást, mely szerint a nem iskolai extrakurrikuláris programokon való részvétel nagy anyagi ráfordítást igényel a szülőktől, így ezeket a jobb anyagi helyzetű családok veszik igénybe (Pusztai 2009).

\section{A kutatás bemutatása}

\subsection{A minta ismertetése}

Jelen kérdőíves kutatásunk mintája a különböző régiókban müködő, nyolc müvészeti és zenemüvészeti szakgimnázium népzene tanszakos 9-14. évfolyamos diákja $(\mathrm{N}=103)$. A kérdöívet a próbamérést követő javítás után az iskolában töltötték ki a növendékek. Az adatokat, válaszokat SPSS statisztikai programmal dolgoztuk fel. A középfokú népzeneoktatás a közoktatási intézményrendszerben (kurrikuláris helyszínen) a 2016/17-es tanévtől müvészeti szakgimnáziumokban történik. Az Oktatási 
Hivatal OM azonosítók és tanulmányi területek jegyzéke a középfokú iskolai felvételihez a 2019/2020. tanévre címü dokumentumában nyolc szakgimnázium hirdetett népzenei képzést. Az iskolák területi eloszlása, fenntartója, és feladatellátása szerint is változatosságot mutat. Három szakgimnázium múködik Budapesten, egy a Közép-Dunántúl, egy az Észak-Alföld, egy a Dél-Alföld, egy az ÉszakMagyarország és egy a Közép-Magyarország régióban. Öt intézmény központi állami, két szakgimnázium egyházi fenntartású (egyházközség és szerzetesrend müködteti), egy pedig felsőfokú oktatási intézményhez, a Liszt Ferenc Zenemúvészeti Egyetemhez tartozik.

\subsection{Háttérváltozók vizsgálata}

A mintánkban szereplő válaszadó növendékek a 9-14. évfolyamon tanulnak. Az adatok alapján mind a nyolc szakgimnáziumban zajlott népzeneoktatás 9-12. évfolyamon a 2018/2019-es tanévben (kérdőívünk felvétele idején), öt szakgimnáziumban volt 13. és két szakgimnáziumban volt 14. évfolyam. Az utóbbi évfolyamokon tanulók jelenléte utal az intézményben folyó középfokú szakirányú továbbtanulásra, a felsőfokú tanulmányokra való készülést azonban nem lehet a számokból megállapítani. Érdekes megfigyelni a szakgimnáziumi népzeneoktatásban résztvevők nemének arányát. Közel háromnegyedük lány (72 százalék), ez az arány ellentmond az egykor a hagyományban működő zenészek nemek szerinti eloszlásának. A „profi” zenészek (cigányzenészek), akik a zenélésböl éltek, túlnyomó részt férfiak voltak. Az „amatörök” (parasztzenészek) között lehetett nő, játszhatott nő paraszti hangszeren, például citerán. Ezeket a hangszereket könnyű „párosítani” az énekléssel (a növendékek 52 százaléka tanul népi éneket, és 32 százaléka citerát). A kérdőívvel a szakok/fötárgyak választását is feltárjuk. A hangszerpárosítás eredményei is a fenti megállapítást támasztják alá: a kérdőíven szereplő ének A szakhoz/fötárgyhoz kapcsolódó B szak/főtárgy 35 százalékban citera, a citera A szak/fötárgy 44 százalékban jár együtt ének B szakkal/fötárggyal. A hegedủ és a brácsa tanulásának százalékértéke (22 és 24 százalék), illetve a hangszerpárosításuk egymással (A szak/fötárgy hegedủ mellett B szak/főtárgy brácsa választása 52 százalék) mutathatja azt, hogy a rövid múltra visszatekintő intézményi népzeneoktatásban még ma is megvan a „klasszikus” hangszerválasztás.

A háttérváltozókra vonatkozó kérdések a növendékek lakóhelyének, a tanév közbeni tartózkodási helyének, az iskolától való földrajzi távolságának feltérképezését is szolgálják. A tanulók 60 százaléka nem lakik otthon, 55 százaléka kollégista, 5 százaléka pedig albérletben vagy rokonoknál lakik. A kollégista középiskolások aránya Magyarországon 2016-ban tíz százalék körül alakult, így a mintám 55 százalékos aránya még akkor is magasnak mondható, ha az országos adatok esetében növekvő tendencia tapasztalható. A növendékek 54 százaléka $50 \mathrm{~km}$-es távolságon belül lakik a szakgimnáziumtól, és csak 26 százalékuk lakik több mint 100 km-re. Annak, hogy a kisebb távolságra élők is beköltöznek a kollégiumba (albérletbe és rokonokhoz), lehetséges oka az, hogy a sajátos képzőhelyeken a növendékek a bejárással nehezebben tudnák megoldani részvételüket a gyakorlásokon, próbákon a megnövekedett óraszámú intézményesített oktatásban és a tanórákon kívüli alkalmakon (tanítási időt követően délután és/vagy este). Az iskolai szervezésű tanórán kívüli iskolai és az iskolán kívüli alkalmak közül egy esetben szignifikáns az összefüggés a lakóhely távolságával Khí-négyzet próbával tesztelve $(\mathrm{p}=0,007)$. Az extrakurrikuláris gyüjtés gyakorisága alacsony a nagy távolság miatt, és ez összefüggésben állhat a családok jövedelmi helyzetével.

A családi helyzet jellemzőinek feltárásában az eredmények szerint nem mutatható ki a mintánkban szignifikáns összefüggés a családszerkezet és a település típusa, valamint a lakóhely távolsága, a tartózkodási hely között. Nem paraméteres Wilcoxon próbával tesztelve szignifikáns eltérés van a szülök iskolai végzettsége között, az anyák magasabb végzettségüek ( $p=0,019)$.

A családtagok meglévő zenei képzettsége, gyakorlata és a nem iskolai szervezésü programokról való információszerzés összefüggésének kereszttáblás vizsgálatában az anyák esetében van szignifikáns eltérés. Ott nagyobb arányban jelent információforrást a család, ahol az anya hivatásszerüen zenél $(\mathrm{p}=0,025)$. 
A családtagok zenei aktivitása összefüggésben állhat a kulturális programokon való részvétellel. Mintánkat vizsgálva szignifikáns a korreláció mesterfokon hangszeren játszó családtag megléte és az operalátogatás között. Akinek van legalább egy mesterfokon játszó családtagja, az 16 százalékban évente néhányszor megy operába, akinek nincs, az csak 6 százalékban látogat évente néhányszor operaelőadást $(\mathrm{p}=0,043)$.

Kutatásunkban arra is keressük a választ, a népzenét tanuló szakgimnazisták közül gyakrabban járnake kulturális programokra azok, akik magasabb iskolai végzettségü szülőkkel rendelkeznek. Az apa végzettsége az operalátogatás gyakoriságára, az anya végzettsége a komolyzene-hallgatás gyakoriságára hat szignifikánsan. Akinek legalább föiskolai végzettségü édesapja van, 16 százalékban évi néhányszor operába megy, akinek nincs, az csak 3 százalékban néz meg operaelőadást ( $\mathrm{p}=0,001$ ). Ahol a családban legalább főiskolai végzettségü az anya, 29 százalékban hallgat havonta komolyzenét, ahol nem, ott csak 9 százalékban ( $\mathrm{p}=0,017)$.

Vizsgálatunk a családok anyagi helyzetére is kiterjed, a kérdőíven felsoroltunk 11 ingóság-, illetve ingatlantípust. A nagyobb értékü fogyasztási cikkekkel való ellátottságra vonatkozó kérdés az objektív vagyoni helyzetet kívánja felmérni. A mintánkban szereplő növendékek családjai a válaszok alapján átlagosan hat, javakhoz sorolható tárggyal rendelkeznek. Hatig átlag alatti, hat felett pedig átlag feletti a jövedelmi helyzet. A családok 38 százaléka jobb, a többi inkább kevésbé jó jövedelmi helyzetben van. Ennek ellenére az iskolai szervezésü tanórán kívüli és az iskolán kívüli népzeneoktatási alkalmakon való gyakori részvétel oka lehet az, hogy közülük több ingyenes, például a verseny vagy a zenekari részvétel. A család szocioökonómiai státusza és a részvételi gyakoriság közötti összefüggés vizsgálata tehát további részkutatást igényel. Így feltárulhat a népzeneoktatás újabb feltételezésként megfogalmazott hátránykompenzáló szerepe is.

\section{Kutatási eredmények}

A kérdőívvel azt is vizsgáljuk, a növendékek véleménye szerint a tanórán kívüli alkalmak mennyire járulnak hozzá a saját szakmai fejlődésükhöz a felsorolt területeken. A kapott eredmények alapján rangsorolhatók a területek, azaz megállapítható, szubjektív megítélésük alapján melyik területet fejlesztik leginkább és legkevésbé az extrakurrikuláris színterek. Ha a teljes mértékben és nagymértékben válaszok százalékos értékeit összeadjuk - a következő sorrend alakul ki: 1. repertoárismeret; 2. technikai tudás; 3. kamarazenélés; 4. előadói rutin és zenei memória; 5 . zenei hallás; 6. stílusismeret; 7. improvizációs készség. A sorrend elején azok a területek állnak repertoárismeret, technikai tudás, kamarazenélés - melyekre az iskolai népzeneoktatás ugyan a tantervben hangsúlyt fektet (a szakgimnáziumi kerettanterv kiemeli például sajátos módszerként az együttzenélést), azonban elmélyítésükhöz szükségesek a (szakgimnáziumi tantervben) 10. évfolyamtól elöírt és az önként vállalt, választott szakmai gyakorlatok, például a szakmai táborok, folklórrendezvények, ahol lehetőség van a közös gyakorlásra, a közösségi zenei tevékenységekre. A repertoárismeret, -bővítés hatással van a tehetségfejlesztés folyamatára és a kamarazenélésre is.

1. táblázat. A növendékek szakmai fejlődéséhez hozzájáruló területek és a hozzájárulásuk százalékos megoszlása

\begin{tabular}{|l|c|c|c|c|c|}
\hline & $\begin{array}{c}\text { teljes } \\
\text { mértékben }\end{array}$ & $\begin{array}{c}\text { nagymérték } \\
\text { ben }\end{array}$ & $\begin{array}{c}\text { teljes mértékben } \\
\text { és nagymértékben } \\
\text { összesen }\end{array}$ & kis mértékben & $\begin{array}{c}\text { egyáltalán } \\
\text { nem }\end{array}$ \\
\hline $\begin{array}{l}\text { hangszeres/énekes } \\
\text { technikai tudás }\end{array}$ & $38.2 \%$ & $50.0 \%$ & $\mathbf{8 8 , 2} \%$ & $11.8 \%$ & $0.0 \%$ \\
\hline repertoárismeret & $51.5 \%$ & $40.8 \%$ & $\mathbf{9 2 , 3 \%}$ & $6.8 \%$ & $1.0 \%$ \\
\hline
\end{tabular}




\begin{tabular}{|c|c|c|c|c|c|}
\hline stílusismeret & $38.6 \%$ & $37.6 \%$ & $76,2 \%$ & $20.8 \%$ & $3.0 \%$ \\
\hline előadói rutin & $53.4 \%$ & $33.0 \%$ & $86,4 \%$ & $12.6 \%$ & $1.0 \%$ \\
\hline zenei hallás & $35.9 \%$ & $44.7 \%$ & $80,6 \%$ & $18.4 \%$ & $1.0 \%$ \\
\hline zenei memória & $49.5 \%$ & $36.9 \%$ & $86,4 \%$ & $10.7 \%$ & $2.9 \%$ \\
\hline improvizációs készség & $40.2 \%$ & $26.5 \%$ & $66,7 \%$ & $27.5 \%$ & $5.9 \%$ \\
\hline kamarazenélés & $60.8 \%$ & $26.5 \%$ & $87,3 \%$ & $11.8 \%$ & $1.0 \%$ \\
\hline
\end{tabular}

A kérdőíves kutatásunk arra is irányul, hogy a zenetanulás nem kognitív komponensei, a felsorolt készségek, képességek, a személyiség fejlődésének egyes elemei a szakgimnazisták szerint melyik népzeneoktatási színtéren valósul meg inkább. Az oktatás módszereivel, azok különbözőségével lehet összefüggésben az affektív tényezők közül a népzeneoktatásban átélt pozitív stressz megélésnek aránya az iskolai és az iskolán kívüli színtereken. A 2. táblázatban látható, hogy a válaszadók 40 százaléka - több mint egyharmada - az iskolában, tanórán éli át a pozitív stresszt, 18 százalékuk az iskolai szervezésủ tanórán kívüli alkalmakon, 15 százalékuk az iskolán kívül szervezett alkalmakon, 28 százalékuk pedig egyik helyen sem. A táblázatból az is leolvasható, melyik alkalmon milyen százalékban valósulnak meg a komponensek, és a színek jelölik a legmagasabb arányokat. Így szembeötlö a tehetségfejlesztés tanórai magas elöfordulása, az iskolán kívüli alkalmakon való élményszerzés és flow, valamint az önbizalom magas értéke. Jellemző az iskolán kívüli színterekre az aktív közösségi élet (a tanórán kívüli alkalmakon is magas arányban valósul meg) és a kapcsolatok kialakításának magas értéke. A motiváltság, a koncentráció és az önfegyelem legmagasabb százalékaránya a tanórai népzenetanuláshoz kötődik. Érdekes megfigyelni, hogy az odafigyelés másokra százalékértéke a tanórán a legalacsonyabb, ez fakadhat egyrészt az egy tanár - egy diák egyéni munkaformából, másrészt feltételezhetően az iskolán kívüli alkalmakon nagyobb eséllyel játszanak együtt olyan zenésztársakkal a növendékek, akikkel még nem vagy keveset muzsikáltak együtt, ezért nagyobb szükség van arra, hogy egymás jelzéseire fókuszáljanak. Az együttmüködés százalékos értéke az iskolai szervezésben tanórán kívül a legmagasabb, erre magyarázat lehet az iskolai baráti, aktív zenei közösség.

2. táblázat. A növendékek szakmai fejlődéséhez hozzájáruló területek és a hozzájárulásuk százalékos megoszlása

\begin{tabular}{|l|c|c|c|c|c|}
\hline & $\begin{array}{c}\text { iskolában, } \\
\text { tanórán }\end{array}$ & $\begin{array}{c}\text { iskolai } \\
\text { szervezésben } \\
\text { tanórán kívül }\end{array}$ & iskolán kívül & $\begin{array}{c}\text { egyik helyen } \\
\text { sem }\end{array}$ & nincs válasz \\
\hline önkifejezés & $33 \%$ & $19 \%$ & $45 \%$ & $3 \%$ & $0 \%$ \\
\hline tehetségfejlesztés & $79 \%$ & $13 \%$ & $8 \%$ & $0 \%$ & $0 \%$ \\
\hline élményszerzés & $2 \%$ & $42 \%$ & $55 \%$ & $1 \%$ & $0 \%$ \\
\hline motiváltság & $42 \%$ & $19 \%$ & $39 \%$ & $0 \%$ & $0 \%$ \\
\hline
\end{tabular}




\begin{tabular}{|l|c|c|c|c|c|}
\hline koncentráció & $72 \%$ & $21 \%$ & $7 \%$ & $1 \%$ & $0 \%$ \\
\hline önfegyelem & $67 \%$ & $21 \%$ & $11 \%$ & $1 \%$ & $0 \%$ \\
\hline flow & $12 \%$ & $32 \%$ & $56 \%$ & $0 \%$ & $0 \%$ \\
\hline stressz & $40 \%$ & $18 \%$ & $15 \%$ & $28 \%$ & $0 \%$ \\
\hline önbizalom & $26 \%$ & $30 \%$ & $44 \%$ & $0 \%$ & $0 \%$ \\
\hline megbízhatóság & $49 \%$ & $26 \%$ & $21 \%$ & $5 \%$ & $0 \%$ \\
\hline kommunikáció & $31 \%$ & $34 \%$ & $32 \%$ & $3 \%$ & $0 \%$ \\
\hline aktív közösségi élet & $6 \%$ & $46 \%$ & $46 \%$ & $2 \%$ & $0 \%$ \\
\hline kapcsolatok kialakítása & $8 \%$ & $32 \%$ & $60 \%$ & $0 \%$ & $0 \%$ \\
\hline odafigyelés & $11 \%$ & $66 \%$ & $23 \%$ & $0 \%$ & $0 \%$ \\
\hline együttmüködés & $16 \%$ & $53 \%$ & $15 \%$ & $0 \%$ & $17 \%$ \\
\hline
\end{tabular}

Kutatásunkban keressük az összefüggést a népzenei tanulmányok kezdetének színtere és az extrakurrikuláris alkalmakon való részvétel gyakorisága között. Nincs szignifikáns különbség abban, hogy azok, akik nem alapfokú müvészeti iskolában/zeneiskolában kezdtek el népzenét tanulni, gyakrabban járnak-e iskolai szervezésen kívüli - extrakurrikuláris - alkalmakra, mint azok, akik ott kezdtek népzenét tanulni. A 3. táblázat eredményeiből a következő tendenciák rajzolódnak ki: bárhol is kezdte a növendék a népzenetanulást, a felsoroltak közül gyakran részt vesz táborban, táncházban, fellépőként és nézőként népzenei rendezvényen és zenekarban, így megvalósul két zenei viselkedésforma (hallgató és előadó). Ezek tantervben is ajánlott színterei a középfokú népzeneoktatásnak. Szintén szerepel a tantervben népzeneoktatási színtérként a gyüjtés (még élő adatközlőktől) terepen, azonban az alapfokú müvészeti iskolában/zeneiskolában kezdett növendékek 68, a nem alapfokú müvészeti iskolában/zeneiskolában kezdett növendékek 73 százaléka soha nem vett részt népzenei gyüjtésben. Ezen szükséges változtatni a népzeneoktatás iskolai gyakorlatában az okok feltárásával.

3. táblázat. A népzenei tanulmányok kezdetének színtere és az extrakurrikuláris alkalmakon való részvétel gyakorisága százalékos arányban

\begin{tabular}{|l|c|c|c|c|c|c|}
\hline \multirow{2}{*}{$\begin{array}{l}\text { extrakurrikuláris } \\
\text { színterek }\end{array}$} & \multicolumn{2}{|c|}{$\begin{array}{c}\text { alapfokú müvészeti iskolai } \\
\text { népzenetanulási kezdet }\end{array}$} & \multicolumn{2}{c|}{$\begin{array}{c}\text { nem alapfokú müvészeti iskolai } \\
\text { népzenetanulási kezdet }\end{array}$} \\
\cline { 2 - 7 } & gyakran & ritkán & soha & gyakran & ritkán & soha \\
\hline táncház & $49 \%$ & $48 \%$ & $3 \%$ & $58 \%$ & $33 \%$ & $10 \%$ \\
\hline
\end{tabular}




\begin{tabular}{|l|c|c|c|c|c|c|}
\cline { 2 - 6 } tábor & $66 \%$ & $20 \%$ & $15 \%$ & $59 \%$ & $31 \%$ & $10 \%$ \\
\hline koncerten fellépő & $47 \%$ & $45 \%$ & $8 \%$ & $48 \%$ & $48 \%$ & $5 \%$ \\
\hline koncerten néző & $54 \%$ & $43 \%$ & $3 \%$ & $42 \%$ & $55 \%$ & $3 \%$ \\
\hline verseny & $16 \%$ & $39 \%$ & $45 \%$ & $6 \%$ & $39 \%$ & $55 \%$ \\
\hline szakmai fórum & $33 \%$ & $46 \%$ & $21 \%$ & $31 \%$ & $46 \%$ & $23 \%$ \\
\hline zenekar & $48 \%$ & $36 \%$ & $16 \%$ & $60 \%$ & $18 \%$ & $23 \%$ \\
\hline szakkör & $11 \%$ & $27 \%$ & $61 \%$ & $15 \%$ & $30 \%$ & $55 \%$ \\
\hline gyüjtés & $8 \% !$ & $23 \%$ & $68 \%$ & $0 \% !$ & $28 \%$ & $73 \%$ \\
\hline
\end{tabular}

A növendékek extrakurrikuláris színtereken való részvételi gyakoriságát vizsgálva szembetűnő az adatok azonossága és különbözősége. A táncházi és a tábori részvétel az iskola szervezésén kívüli alkalmakon magasabb százalékértékü. Figyelemre méltó, hogy fellépőként és nézőként szinte azonos arányban közremüködnek a növendékek koncerteken, illetve a zenekarban való szereplésük is ugyanolyan arányú.

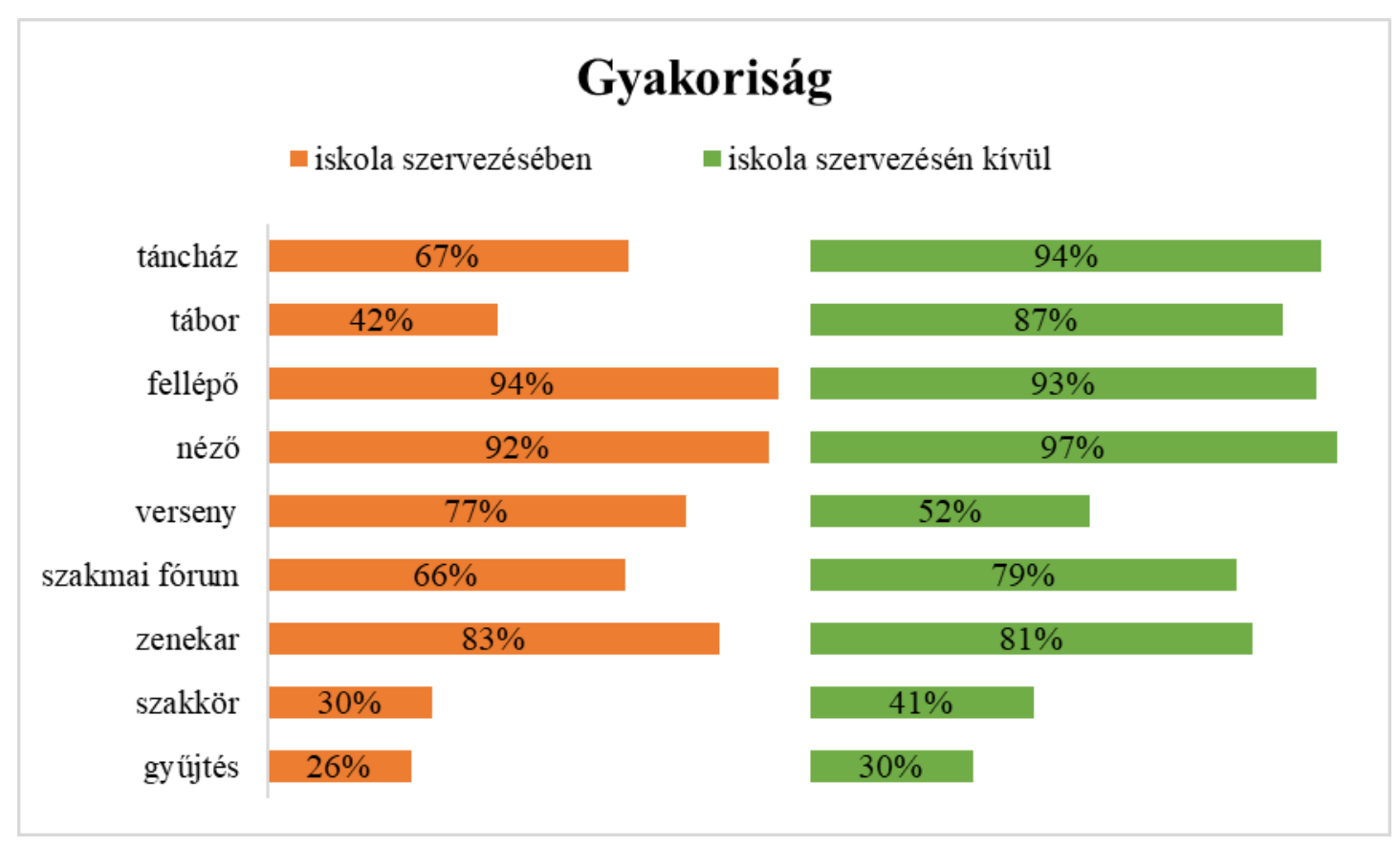

1. ábra. Extrakurrikuláris alkalmakon való részvétel a gyakran és ritkán válaszok együttes arányában

Regresszió-analízis segítségével nyert adatok szerint két tényező hat arra, hogy valaki extrakurrikuláris színtéren zenekari foglalkozáson vesz részt. Az egyik a régió: a budapestiek nagyobb eséllyel vesznek részt extrakurrikuláris zenekari foglalkozáson (a nem budapestiekhez képest), illetve a nemek közül a fiúk azok, akik nagyobb arányban közremüködnek zenekarban. A vizsgálat magyarázó változói: nem, évfolyam, településtípus, régió (Budapest vagy vidék), apa végzettsége és anya végzettsége. A megmagyarázott változó (célváltozó): részvétel extrakurrikuláris zenekarban 
(ritkán vagy soha, gyakran). Ez egy modell szintủ vizsgálat, tehát az eredmény interpretálható úgy is, hogy a budapesti fiúk vesznek részt a legnagyobb arányban. A többi tényező hatása pedig nem szignifikáns, tehát az, hogy milyen településtípuson lakik valaki, az nem meghatározó.

Ha azt vizsgáljuk, inkább az iskola szervezésén kívül nyújtottak-e élményeket a különböző tevékenységek azoknak, akik nem alapfokú müvészeti iskolában/zeneiskolában kezdtek el népzenét tanulni, akkor a felsoroltak esetében egyik esetben sem beszélhetünk szignifikáns különbségröl. Mégis érdemes elemezni néhány adatot, mert a tevékenységek élményt nyújtó volta mellett a zeneoktatás tanórai és nem tanórai módszereiröl is képet nyújtanak. Az eredeti hangzó- és képi anyag felhasználása túlnyomó részt az iskolai tanórák jellemzője. Az adatközlőkkel való találkozás élményének százalékos aránya ellenben kicsi a tanórán, így a gyüjtés, illetve a tőlük való tanulás lehetősége sem valósulhat meg a népzeneoktatásnak ebben a szervezeti formájában. A tanárral való együttzenélés élményében nagy százalékban részesülnek a növendékek a tanórán, ez kifejezheti a pozitív tanár-diák kapcsolatot, a tanár-diák tanítás-tanulás folyamatát, és az abban rejlö szakmai és személyiségfejlesztés megvalósítását is. A tananyag egyéni érdeklődés szerinti kiválasztásának élménye szintén jellemző a tanórára, és az egy tanár - egy diák személyes interakcióval együtt lehetőséget nyújt az adaptív, differenciált oktatásra, a tehetséggondozásra és a felzárkóztatásra. (A szakgimnáziumi kerettanterv szerint három tényező határozza meg a zenei anyag kiválasztását: a tanuló technikai tudása, muzikalitása és zenei érettsége.) A baráttal, más növendékkel való együttzenélés jellemzően inkább a kurrikuláris színtéren kívül nyújt élményt. Az eredmények további összefüggésben állhatnak a népzeneoktatás látens pedagógiai hatásrendszerével.

Megvizsgáltuk, hogy a válaszadók hol kezdték népzenei tanulmányaikat. Az eredmények azt mutatják, hogy a növendékek közül 63 fö kezdte népzenei tanulmányait alapfokú müvészeti iskolában, és 6 fö jelölt meg valamilyen más közoktatási intézményt. 34-en jelölték meg kezdeti színtérnek a szakkört, tábort, családot, magántanárt.

Vizsgált mintánkban azok, akik családban kezdték a népzenetanulást, nem szereznek gyakrabban tudomást a családban a nem iskolai szervezésủ programokról. Mind a családban, mind az intézményi keretek között kezdett növendékek esetében a barátok az elsődleges forrásai a programokról való információknak, őket követik a tanárok és végül a média. A családoknak van legkisebb szerepe abban, hogy a növendékek informálódjanak nem iskolai szervezésü programok felöl. Az eredmények feltételezik, hogy az életkori sajátosságoknak megfelelően erős a kortársakkal való kapcsolatrendszer és annak hatása. A zeneoktatás egyik sajátosságából - az egy tanár - egy diák kapcsolatból - eredően a tanári szerephez hozzátartozik az ilyen típusú tájékoztatás és a részvételre való ösztönzés, a média szerepe pedig feltételezhetően azért ilyen jelentős, mert a mintában szereplő növendékek a média fogalmán inkább a közösségi médiát érthették az egyirányú kommunikációs csatornákkal (televízió, rádió) szemben.

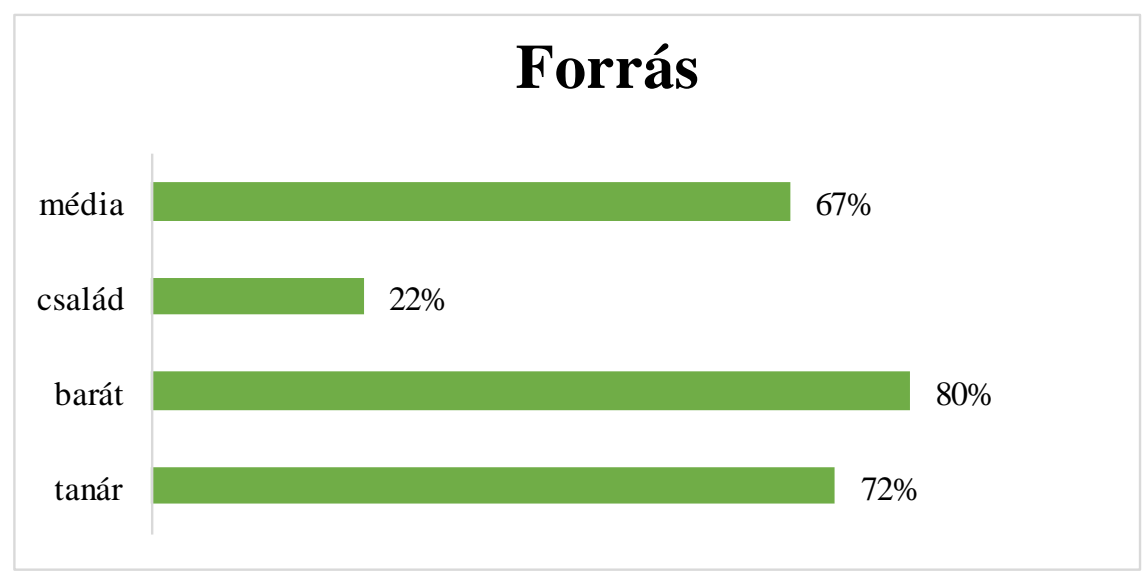

2. ábra. Az extrakurrikuláris alkalmakról szóló információk forrása 


\section{4. Összegzés}

Kutatásunkban a népzeneoktatás kurrikuláris és extrakurrikuláris színtereit tártuk fel papír alapú kérdőíves adatgyüjtés segítségével. Mind a tevékenységek, mind az élményszerzés vizsgálatának eredményei a népi hangszeres zenélés aktivitását teszik a középpontba mindkét helyszínen. Feltételezésünknek (H2) megfelelően a népzeneoktatás szerepei - feladatai és céljai - a növendékek szerint eltérő mértékben valósulnak meg a két színtéren, és a diákok szerint az extrakurrikuláris színtéren az élményeket formáló zenei tevékenységek gazdagabbak, és a zenei aktivitást jobban igénylik, mint a tanórákon megvalósulók. Abban azonban a gyüjtés kivételével nem mutatkozik szignifikáns eltérés, hogy a lakóhely és az iskola távolsága mennyire befolyásolja a részvételt, illetve a népzenetanulás kezdetének színtere sem befolyásolja a részvételi gyakoriságot és az ott átélt élményeket. Az eredmények alapján látható, hogy - hipotézisünket $(\mathrm{H} 1)$ igazolva - nagyobb az aránya azoknak a tanulóknak, akik a kurrikuláris színtérről keresnek fel extrakurrikuláris helyszíneket is (például szakmai tábort, táncházat), mint azoknak, akik utóbbi színtérről lépnek az intézményes oktatásba. Annak azonban, hogy hol kezdődött a növendék népzenetanulása, nincs befolyásoló hatása arra, honnan szerez a növendék információt az iskolán kívüli alkalmakról. A szakgimnazisták korosztályában meghatározó információforrás a baráti kör, megfigyelhető a kortársak befolyása. Nincs szignifikáns különbség abban, gyakrabban jutnak-e el a növendékek tanórán kívüli iskolai és/vagy iskolán kívüli népzeneoktatási alkalmakra, és az sem meghatározó e tekintetben, ki hol kezdte a népzenét tanulni. A táncházban és a táborokban való részvétel a gyakoribb extrakurrikuláris színtéren, a versenyeken inkább az iskolai szervezés az elterjedtebb, fellépőként és nézőként szinte azonos arányban közremüködnek a növendékek koncerteken, illetve a zenekarban való szereplésük is ugyanolyan arányú. A következő (H3) hipotézisünkkel kapcsolatban megállapítható, és az egyes színterek élményszerüségét vizsgálva látható, hogy az eredeti hangzó- és képi anyag felhasználása túlnyomó részt az iskolai tanórák jellemzője. Az adatközlőkkel való találkozás élményének százalékos aránya ellenben kicsi a tanórán, így a gyüjtés, illetve a tölük való tanulás lehetősége sem valósulhat meg a népzeneoktatásnak ebben a szervezeti formájában.

A tanárral való együttzenélés élményében nagy százalékban részesülnek a növendékek a tanórán, és a tananyag egyéni érdeklődés szerinti kiválasztásának élménye szintén jellemző a tanórára. A baráttal, más növendékkel való együttzenélés jellemzően szintén inkább a kurrikuláris színtéren kívül nyújt élményt. A tehetségfejlesztés inkább tanórán fordul elő, viszont a tanórán kívüli alkalmakon az élményszerzésnek, a flownak, valamint az önbizalomnak van magas értéke. Jellemző az iskolán kívüli színterekre még az aktív közösségi élet és a kapcsolatok kialakításának magas százalékaránya. A motiváltság, a koncentráció és az önfegyelem legmagasabb százalékaránya a tanórai népzenetanuláshoz kötődik. A növendékek az extrakurrikuláris alkalmak hozzájárulását a saját szakmai fejlődésükhöz (a teljes mértékben és a nagymértékben válaszokat összeadva) magasra - 92,3 százalék és 76,2 százalék közé - értékelik. Az eltérő arányok a fejlődési területek rangsorolását teszik lehetővé. A háttérváltozók jelen analízise (H4) nem ad teljes képet a családok gazdasági és kulturális tőkével való ellátottságának és a népzeneoktatásban való részvétel összefüggéséről. Az adatok további elemzése választ adhat arra a kérdésre, van-e a népzeneoktatásnak mérhető szocioökonómiai és szociokulturális hátrányokat kompenzáló szerepe, ereje. Vizsgálatunkkal és tanulmányunkkal szeretnénk hozzájárulni a népzeneoktatás területén hiányzó és szükséges kutatási eredmények gyarapításához.

\section{Irodalomjegyzék}

Agócs Gergely (2010): A mesterség elsajátításának társadalmi intézménye a cigányzenészek körében.

http://folkradio.hu/folkszemle/agocs amestersegelsajatitasa/index.php (letöltés: 2016.01.10).

Bárdossy Ildikó (2011): Lehetséges kérdések és válaszok a curriculumfejlesztéshez. Pécs, Pécsi Tudományegyetem Bölcsészettudományi Kar Neveléstudományi Intézet Nevelés- és Oktatáselméleti Tanszék http://janus.ttk.pte.hu/tamop/tananyagok/curriculum/index.html (letöltés: 2017.10.10).

Báthory Zoltán (1997): Tanulók, iskolák, különbségek. Budapest, Okker Kiadó, 146, 158, 160., 179 190. 
Béres János (1979): Tanulságok a kecskeméti népzenei találkozó után. Magyar Nemzet 1979 In (Sebő F. szerk.) (2007): A táncház sajtója. Válogatás a korai évekből 1968-1992. Budapest, Timp Kiadó, $130-131$.

Dobszay László (2009): A népzene pedagógiai jelentősége. In (Sebő F. szerk.): Népzenei olvasókönyv. Budapest, Hagyományok Háza, 262.

Dragony Gábor (2017): Extrakurrikuláris lehetőségek a népzeneoktatásban. In (Kerülö J. és Jenei T. szerk.): Új kutatások a neveléstudományban 2017. Debrecen, Kreatív Help Bt., 113-121.

Dragony Gábor (2018): A népzeneoktatás múltjáról és jelenéröl a müvészeti nevelés tükrében. In (Váradi J. és Szücs T. szerk): A zenepedagógia múltja, jelene és jövője. Debrecen, Debreceni Egyetemi Kiadó, 99-114.

Halmos Béla (2006): A táncházmozgalomról. In (Sándor I. szerk.): A betonon is kinő a fú. Tanulmányok a táncházmozgalomról. Budapest, Hagyományok Háza, 7-20.

Johansen, Geir (2010): Modernity, Identity, and Musical Learning. In (Ruth Wright szerk.): Sociology and Music Education. Ashgate, 155-163.

Kiss Ferenc (2006): Számvetés - a népzenei mozgalom három évtizede. In (Sándor Ildikó szerk.): A betonon is kinő a fü. Tanulmányok a táncházmozgalomról. Budapest, Hagyományok Háza, 67-70.

Könczei Csongor (2011): A kalotaszegi cigányzenészek társadalmi és kulturális hálózatáról. Kriza Könyvek 36, Kriza János Néprajzi Társaság, 108-117.

Mark, Michael L. (2002): Nonmusical outcomes of music education: Historical considerations. In (Richard Corwell - Carol Richardson szerk.): The New Handbook of Research on Music Teaching and Learning: A Project of the Music Educators National Conference. USA, Oxford University Press, $1045-1052$.

Nahalka István (2003): Túl a falakon - Az iskolán kívüli nevelés módszerei. Budapest, Gondolat Kiadói Kör, 7., 14.

Pásku Judit - Münnich Ákos (2000): Az extrakurrikuláris oktatás nem specifikus hatásai. In: Magyar Pedagógia 100. évf. 1. szám 59-77.

Pusztai Gabriella (2009): A társadalmi tőke és az iskolai pályafutás. Budapest, Új Mandátum Kiadó

http://mek.oszk.hu/12100/12193/12193.pdf letöltés: 2019. január 24. 54-56., 130 - 165.

Sebő Ferenc (2009): Népzenei olvasókönyv. Budapest, Hagyományok Háza, 13-94.

Stachó László (2008): Érték, öröm és haszon a Kodály módszerben. In: Parlando, 2008, 2. szám, 2128. http://www.parlando.hu/Kodaly-emlekev-Szeged-2008-2.htm letöltés: 2016. április 23.

Trencsényi László (2006): A nevelési színtereket magába foglaló rendszer elemei. In (Trencsényi L. szerk.): Iskolán kívüli nevelés. Bölcsész Konzorcium, 16-55.

Váradi Judit (2019): Az élménypedagógia szerepe a müvészeti nevelésben. In Magyar Müvészet, 7. 3. sz. 59-66.

Váradi Judit (2010): How to educate an audience to acquire a taste for classical music (Hogyan neveljünk értő közönséget a komolyzenének? PhD disszertáció, University of Jyväskylä, Jyväskylä

Szakképzési kerettanterv a(z) XLII. Előadómüvészet ágazathoz tartozó 5421206 Népzenész II vonós/húros szakmairány szakképesítéshez 1-73. https://www.nive.hu/index.php?option=com content\&view=article\&id=713:szakkepzesi-kerettantervek 302016viii31ngmrendelet\&catid=10\&Item id=166 (letöltés: 2017.04 .18 ).

A közoktatás indikátorrendszere 2017 (szerkesztette: Varga Júlia) MTA Közgazdaság- és Regionális Tudományi Kutatóközpont Közgazdaság-tudományi Intézet https://www.mtakti.hu/wpcontent/uploads/2018/02/A_kozoktatas_indikatorrendszere_2017.pdf 112. (letöltés: 2019.08.10). 
OM azonosítók és tanulmányi területek jegyzéke a középfokú iskolai felvételihez a 2019/2020. tanévre. https://www.oktatas.hu/pub_bin/dload/kozoktatas/beiskolazas/2019/OM_azonosito2019/Tag KodJegyzek.pdf (letöltés: 2019.01.28).

\section{Szerzó}

Dragony Gábor, University of Nyíregyháza (Hungary). E-mail: dragony.gabor@gmail.com 
